\title{
Reasonability to use device for making horizontal wedge thrust of rolling stand
}

\author{
Viktor Artiukh ${ }^{1, *}$, Vladlen Mazur ${ }^{2}$, Sergey Kargin ${ }^{3}$, and Nikolay Bushuev ${ }^{4}$ \\ ${ }^{1}$ Peter the Great St.Petersburg Polytechnic University, Polytechnicheskaya, 29, St. Petersburg, \\ 195251, Russia \\ ${ }^{2}$ LLC «Saint-Petersburg Electrotechnical Company», Pushkin, Parkovaya, 56, Saint-Petersburg, \\ 196603, Russia \\ ${ }^{3}$ Pryazovskyi State Technical University, Universytets'ka, 7, Mariupol, 87500, Ukraine \\ ${ }^{4}$ Moscow State University of Civil Engineering, Yaroslavskoe shosse, 26, Moscow, 129337, Russia
}

\begin{abstract}
Necessity and reasonability to use gapless connection between contact surfaces of lining straps of work rolls chocks and facing strips of housings (inner lining straps of back-up rolls chocks) to reduce dynamic horizontal forces during rolling and increase durability of equipment are considered. Technical solution is described on base of roughing reversing rolling stand of thick sheet rolling mill 3000 of PJSC 'ILYICH iron and steel works' (Mariupol city, Ukraine) which can be used on most heavy loaded sheet and tube rolling mills.
\end{abstract}

\section{Introduction}

Practically, stands of rolling mills undergo bigger loads when masses of rolled metal are increased compared to initial ones. Moreover, rolling speeds are increased in order to improve productivity of rolling mills but it results in increase of dynamics of stands main drive lines [1-6]. Dynamics of rolling stands can result in their expensive accidental breakdowns. In addition, dynamics results in plastic deformation of housings windows, facing strips, lining straps and chocks [7-11]. It is expansive to revamp described parts of rolling stands equipment.

\section{Statement of technical problem}

One of the most important dynamic load acting on housings windows, facing strips, lining straps and chocks is horizontal force which can be around $0.3 \ldots 9 \mathrm{MN}$ [12-14] due to horizontal gaps between details of chocks and housings. That is why it is necessary to use designs and technological solutions which can provide gap-free connections during loading of rolling stands.

The most interesting designs and technical solutions of use of devices for making horizontal wedge thrust of rolling stands and removal of gaps between facing strips and lining

\footnotetext{
${ }^{*}$ Corresponding author: artiukh@mail.ru
} 
straps are based on installation of devices on used equipment $[15,16]$. Their common disadvantages are:

- impossibility to continue rolling when even one wedge thrust unit is broken;

- big specific consumption of materials and damping elements for reduction of shock energy of top work rolls (TWRs) assemblies and bottom work rolls (BWRs) assemblies against housings.

Technical solution which has not above given disadvantages and provides gap-free connections between facing strips and lining straps during loading of rolling stands is described in this paper. Installation of devices for making horizontal wedge thrust is shown on base of reversing roughing rolling stand of thick sheet rolling mill 3000 of PJSC 'ILYICH iron and steel works' (Mariupol city, Ukraine). Places of proposed installation are chosen reasonably due to big amount of done scientific and technical jobs for the reversing rolling stand since 1983 year $[17,18]$ where necessary technical data is given.

Detailed description of the device is shown on base of BWR chock on drive side. The technical solution is given below by description, schemes and drawings:

- the rolling stand (general view from drive side) is on fig. 1;

- section A-A (from fig. 1, drive side) is on fig. 2;

- section B-B (from fig. 2, work and rest positions) is on fig. 3.

The 4-Hi rolling stand with installed devices for making horizontal wedge thrust (refer to fig. 1) consists of chocks pos. 1 and pos. 2 of top back-up roll (TBUR) pos. 3 and bottom back-up roll (BBUR) pos. 4 which are in contact with corresponding work rolls (WRs) pos. 5 and pos. 6. TWR chocks pos. 7 are installed in slots of TBUR chocks pos. 1 and BWR chocks pos. 8 are installed in window of housings pos. 20.

\section{Materials of the research}

Devices for making horizontal wedge thrust of the rolling stand work in below given order. During changes of TWR pos. 5 and BWR pos. 6 with their chocks pos. 7 and 8 drive wedges pos. 15 are in rest positions. After installation of chocks pos. 7 and 8 in work positions nuts pos. 18, washers pos. 19 and rods pos. 13 (parts of fixing devices pos. 14, refer to fig. 2) move drive wedges pos. 15 to work position. It results in move of movable wedges pos. 16 and inserts pos. 17 (refer to fig. 3) that uniformly compress by necessary value $\delta=1 \ldots 3 \mathrm{~mm}$ inserts pos. 17, lining straps pos. 11 and 12 (pos. 11, 12 and 17 are made from elastic material). As a result, gaps $\Delta$ (refer to fig. 3) between contact surfaces of facing strips pos. 9 and 10, lining straps pos. 11 and 12 are fully eliminated that reduces horizontal impacts of TWR assemblies and BWR assemblies against housings pos. 20 by several times during metal-in (metal bite) by WRs and metal-out.

During changes of gap between WRs (pos. 5 and 6) there is no need to move drive wedges pos. 15 to rest position because of usage of inserts pos. 17, lining straps pos. 11 and 12 made from elastic material and it does not affect movements of chocks pos. 7 and 8 . In addition, usage of inserts pos. 17, lining straps pos. 11 and 12 made from e.g. polyamide, polypropylene, polyethylene [19,20] or polyurethane [21-24] with high energy-efficiency provides uniform distribution of the horizontal force between contact surfaces of lining straps pos. 11 and 12, chocks pos. 7 and 8, facing strips pos. 9 and 10, chocks pos. 1 and housings pos. 20. It is reasonable to make inserts pos. 17, lining straps pos. 11 and 12 from polyamide or polypropylene when there are low values of the horizontal forces and they should be made from polyethylene or polyurethane when there are high values of the horizontal forces. 


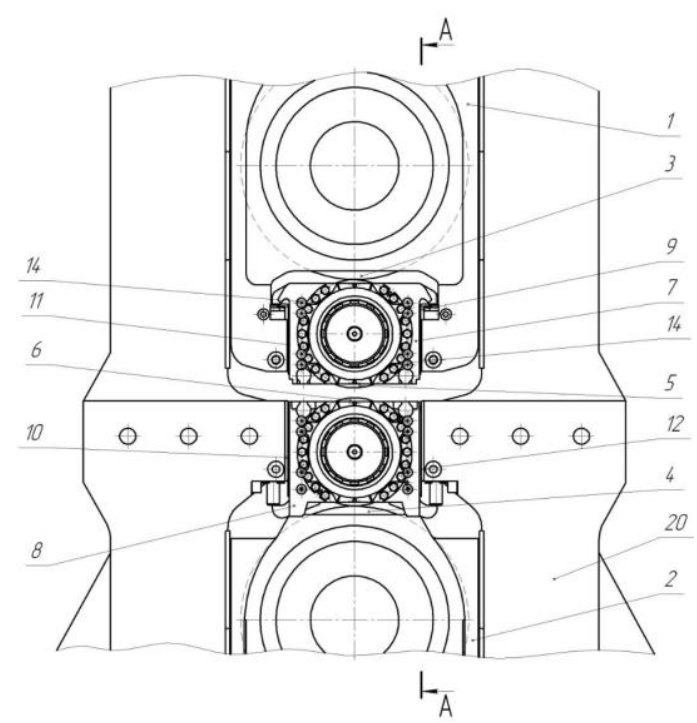

Fig. 1. General view of the rolling stand with the devices for making horizontal wedge thrust from drive side.

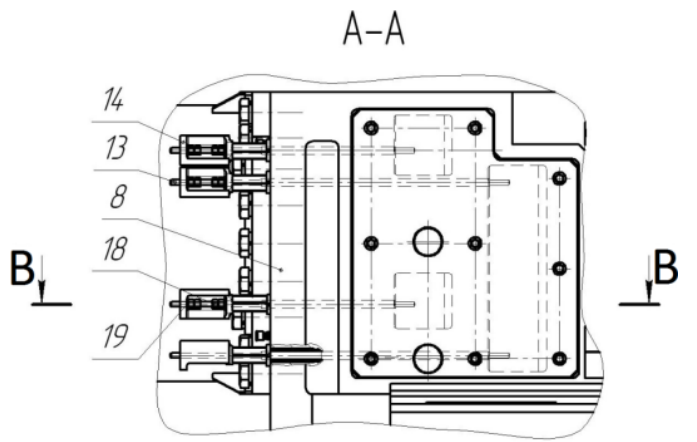

Fig. 2. General view of the device for making horizontal wedge thrust installed inside BWR chock on drive side.

\section{B-B B-B}

a)

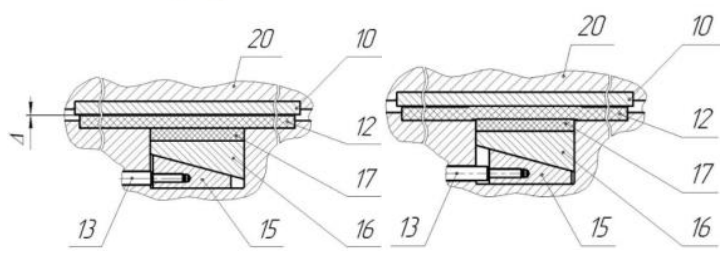

b)

Fig. 3. Section of the device for making horizontal wedge thrust: $a$ - rest position; $b$ - work position.

Analytical and stress calculations of the device are done. Their results prove reasonability to use the device on numerous rolling stands that can reduce horizontal impact energy of TWR assemblies and BWR assemblies against housings (back-up rolls chocks). In addition, it helps to decrease values of stands elements horizontal vibration.

Results of stress calculations of the device for making horizontal wedge thrust installed on base of BWR chock (drive side) of reversing roughing rolling stand of thick sheet rolling 
mill 3000 are shown below. Von Mises stresses (for steel details) and compressive stress (for lining strap and insert) were calculated during rolling in a system consisted of:

- BWR chock from drive side, material steel 30HGSFL according to CIS State standard 977-75;

- details of the device: lining strap and insert are made from polyurethane; facing strip, wedges and rods are made from steel $080 \mathrm{M} 46$ according to B.S. 970; enough part of housing made from steel 161 grade 430 according to B.S. 1504 (76).

FEM mathematical model (MM) was created (refer to fig. 4) where all details are in work positions and it was loaded by the horizontal force $\mathrm{F}=0.51 \mathrm{MN}$. Conditions of contact surfaces interactions, materials properties and geometry of the aforementioned elements are actual according to scientific and practical suggestions [25].

Some FEM stress calculations results are shown on fig. 5 and 6. Calculation results are shown in table 1.

During such loading of lining strap and insert from polyurethane grade Adiprene L-167:

- maximum compressive stress of polyurethane elements is $\sigma=12.27 \mathrm{MPa}$ (refer to fig. 6) and maximum permissible stress compressive stress is $[\sigma]=18 \mathrm{MPa}$;

- maximum theoretical compression of BWR chock polyurethane lining strap and insert towards direction of the horizontal force is $\delta=0.9 \ldots 1.2 \mathrm{~mm}$ that is acceptable. It shows that it needs to provide move of the device for making horizontal wedge thrust equal to $1.2 \ldots 1.5 \mathrm{~mm}$ in horizontal direction for having gapless connection between details.

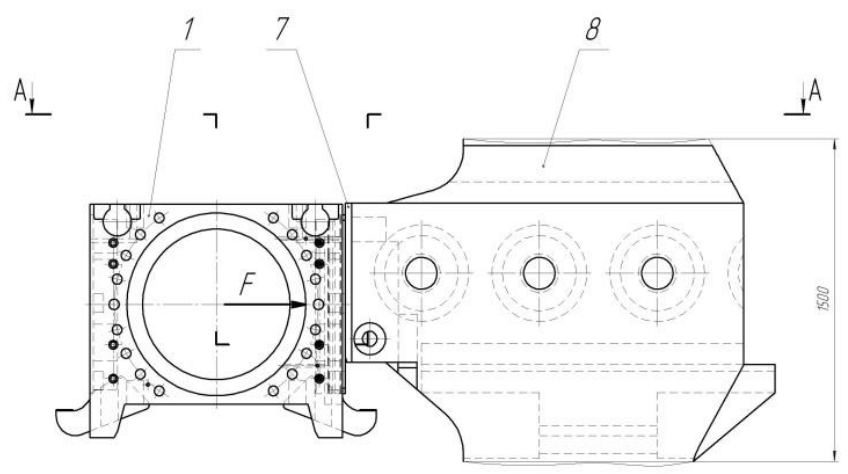

A-A

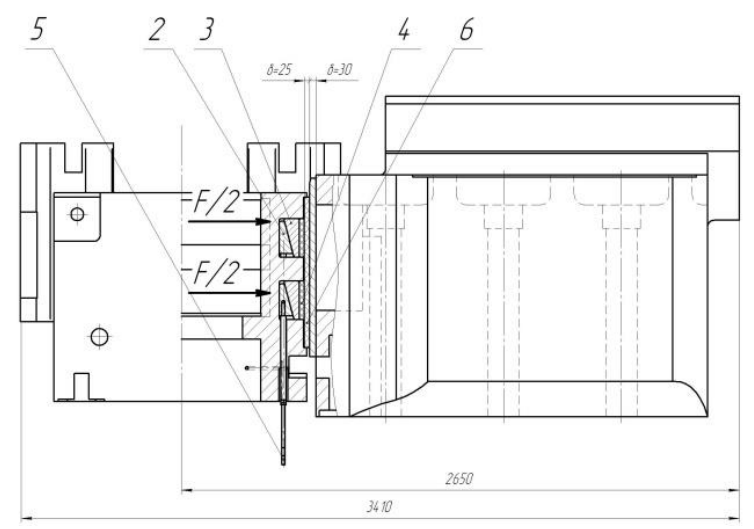

Fig. 4. Loading scheme of MM by horizontal force F: 1 - BWR chock from drive side; 2 - drive wedge; 3 - movable wedge; 4 - insert; 5 - rod; 6 - lining strap of BWR chock; 7 - facing strip; 8 housing. 


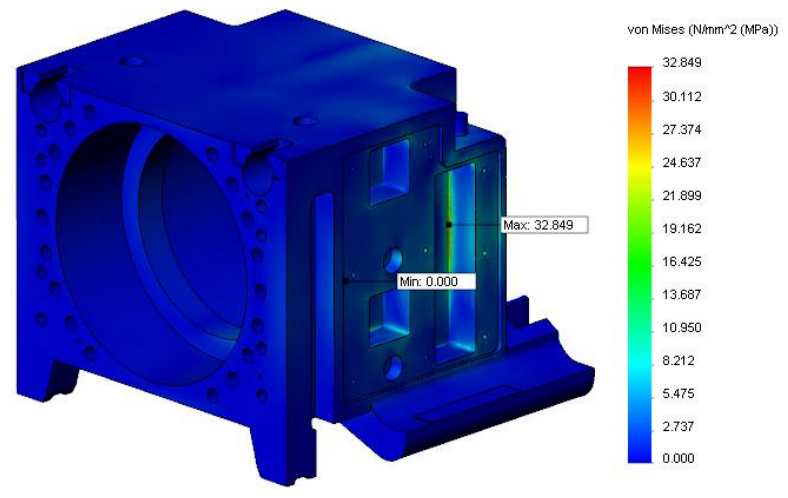

Fig. 5. FEM calculation results of BWR chock from drive side.

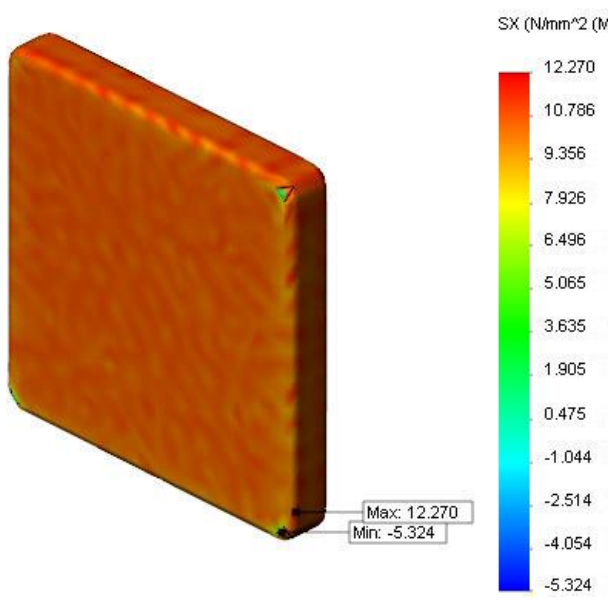

Fig. 6. FEM calculation results of insert.

FEM MM was created with all details that are in use nowadays (without the device for making horizontal wedge thrust) and it was loaded by the horizontal force $\mathrm{F}=0.51 \mathrm{MN}$. Calculation results are shown in table 1 , where $\sigma_{\text {equiv. max }}$ is maximum Von Mises stress, $\sigma_{\text {compres. max }}$ is maximum compressive stress.

Table 1. Maximum stresses calculated in the rolling stand elements.

\begin{tabular}{|c|c|c|c|c|c|c|c|c|}
\hline & Stress & $\begin{array}{l}\text { BWR } \\
\text { chock }\end{array}$ & $\begin{array}{c}\text { Drive } \\
\text { wedge }\end{array}$ & $\begin{array}{c}\text { Movable } \\
\text { wedge }\end{array}$ & $\begin{array}{l}\text { Lining } \\
\text { strap / } \\
\text { insert }\end{array}$ & Rod & $\begin{array}{c}\text { Facing } \\
\text { strip }\end{array}$ & Housing \\
\hline \multirow{2}{*}{$\begin{array}{l}\text { Details of } \\
\text { the device } \\
\text { for making } \\
\text { horizontal } \\
\text { wedge } \\
\text { thrust }\end{array}$} & Gequiv. max, $\mathrm{MPa}$ & 32.849 & 23.167 & 19.006 & & 39.38 & 53.524 & 57.302 \\
\hline & $\sigma_{\text {compres. max }}, \mathrm{MPa}$ & & & & 12.27 & & & \\
\hline $\begin{array}{c}\text { Details in } \\
\text { use }\end{array}$ & $\sigma_{\text {equiv. max }}, \mathrm{MPa}$ & 81.319 & & & 198.686 & & 286.226 & 93.174 \\
\hline
\end{tabular}

Percentage reduction of maximum Von Mises stresses calculated in MM elements of the rolling stand with the device compared to MM elements that are in use nowadays are shown in table 2 . 
Table 2. Percentage reduction of maximum stresses when the device is used.

\begin{tabular}{|c|c|c|c|}
\hline & Housing & Facing strip & BWR chock \\
\hline Reduction, \% & 38.5 & 81.3 & 59.6 \\
\hline
\end{tabular}

In accordance with aforementioned information and figures in table 2 it is reasonable to use the device for making horizontal wedge thrust installed on chocks of TWR and BWR to reduce Von Mises stresses in roughing reversing rolling stand of thick sheet rolling mill 3000.

\section{Conclusions}

Specific consumption of materials and compactness of the device for making horizontal wedge thrust make it possible to install them in WRs chocks of new and modernized heavy loaded rolling stands. Technical solution has patent of Ukraine [26].

\section{Acknowledgments}

The reported study was funded by RFBR according to the research project №16-08-00845a 'Verification and development of models of inelastic deformation at the passive loading'. The authors declare that there is no conflict of interest regarding the publication of this paper.

\section{References}

1. P.V. Krot, IUTAM Bookseries 27(4), 429-442 (2011)

2. V.V. Verenev, V.I. Bolshakov, A.M. Yunakov, Works, Dnepropetrovsk 19, 346-358 (2009)

3. V.V. Verenev, V.I. Bolshakov, N.I. Podobedov, Protection of iron and steel machines from failure 3, 35-39 (1998)

4. V. Kukhar, V. Burko, A. Prysiazhnyi, E. Balalayeva, M. Nahnibeda, East-European Journal of Enterprise Technology 3/7(81), 53-61 (2016) ISSN 1729-3774, DOI: http://dx.doi.org/10.15587/1729-4061.2016.72063

5. V.V. Kukhar, O.V. Vasylevskyi, Metallurgical and Mining Industry 3, 71-78 (2014)

6. E. Sorochan, V. Artiukh, B. Melnikov, T. Raimberdiyev, MATEC Web of Conferences 73, 04009 (2016)

7. DOI: http://dx.doi.org/10.1051/matecconf/20167304009

8. V. Artiukh, V. Mazur, A. Butyrin, Advances in Intelligent Systems and Computing, Springer 692, 212-219 (2018) DOI: https://doi.org/10.1007/978-3-319-70987-1_23

9. N.S. Gharaibeh, M.I. Matarneh, V.G. Artyukh, Research Journal of Applied Sciences, Engineering and Technology 8(12), 1461-1464 (2014)

10. V. Sikulskiy, V. Kashcheyeva, Yu. Romanenkov, A. Shapoval, Eastern European Journal of Enterprise Technologies 4-1 (88), 43-49 (2017) DOI: 10.15587/17294061.2017.108190

11. V. Dragobetskii, A. Shapoval, E. Naumova, IEEE International Conference on Modern Electrical and Energy Systems (MEES), 400-403 (2017) DOI: 10.1109/MEES.2017.8248944

12. V. Artiukh, V. Mazur, E. Pokrovskaya, MATEC Web of Conferences 86, 01030 (2016) DOI: http://dx.doi.org/10.1051/matecconf/20168601030 
13. V. Mazur, V. Artiukh, M.I. Matarneh, Procedia Engineering 165, 1722-1730 (2016) DOI: 10.1016/j.proeng.2016.11.915

14. V. Artiukh, V. Mazur, A. Adamtsevich, MATEC Web of Conferences 106, 04001 (2017) DOI: https://doi.org/10.1051/matecconf/201710604001

15. V. Artiukh, V. Mazur, L. Shilova, MATEC Web of Conferences 106, 03002 (2017) DOI: https://doi.org/10.1051/matecconf/201710603002

16. Y.V. Lipuhin, Steel 1, 56-61 (1987)

17. A.A. Ishenko, Steel 5, 56-58 (2009)

18. A.A. Ishenko, Issledovanie dinamicheskih nagruzok na statini kleti stana $3000 v$ processe prokatki i razrabotka predlozeniy po optimizacii ego raboti, Scientific work report (PSTU, Mariupol, 2006)

19. L.V. Konovalovm, Razrabotka meropriyatiy po stabilizacii raboti glavnih liniy rabochih kletey TLS 3000 MMK im. Ilicha pri proektnoy proizvoditelnosti i ih vnedrenie. Etap III. Razrabotka tehnicheskih trebovaniy na izgotovlenie i ekspluatachiyu osnovnih detaley rabochih kletey stana $i$ predlozeniy $v$ tehnologicheskie instrukcii po proizvodstvu tyazelogo sortamenta, Scientific work report (VNIIMETMASH, Moscow, 1992)

20. L.I. Ogorodov, Mechanics of Composite Materials 30(6), 771-780 (1994)

21. N.N. Alekseev, I.A. Kovalenko, O.N. Stolyarov, B.E. Melnikov, Construction of Unique Buildings and Structures 5(56), 17-32 (2017)

22. S.N. Yakovlev, V.L. Mazurin, Magazine of Civil Engineering 6, 53-60 (2017) DOI: 10.18720/MCE.74.5

23. S.N. Yakovlev, Proektirovanie i osnovy tekhnologii detaley mashin iz poliuretana (Renome, SPb, 2013)

24. F.M.F. Al-Quran, M.E. Matarneh, V.G. Artukh, Research Journal of Applied Sciences, Engineering and Technology 4(11), 1585-1589 (2012)

25. V.G. Artiukh, S.Yu. Karlushin, E.N. Sorochan, Procedia Engineering 117, 938-944 (2015) DOI: 10.1016/j.proeng.2015.08.180

26. V. Artiukh, T. Raimberdiyev, V. Mazur, MATEC Web of Conferences 53, 01039 (2016) DOI: http://dx.doi.org/10.1051/matecconf/20165301039

27. V.G. Artiukh, G.V. Artiukh, V.O. Mazur, Patent 92400 of Ukraine, MKB B 21 B 13/00, Set of rolling stand chocks (2010) 